\title{
Die verdienstes en tekortkominge van 'n alsydige regsakademikus. \\ 'n Kritiese waardering van Johan van der Vyver se bydrae tot die regswetenskap in Suid-Afrika
}

\author{
Lourens du Plessis \\ Departement Publiekreg \\ Universiteit van Stellenbosch \\ STELLENBOSCH \\ E-pos: LMDP@MATIES.SUN.AC.ZA
}

\begin{abstract} Africa

- all-rounder,

- mentor;

- Neo-Calvinist legal philosopher,

- herald of human rights,

- scholar and theoretician of Private Law and

- scholar and theoretician of Public Law.
\end{abstract}

The merits and demerits of an all-rounder legal academic. A critical appraisal of Johan van der Vyver's contribution to legal scholarship in South

This article assesses the contribution of Johan van der Vyver to legal scholarship in South Africa. It does so with reference to his qualities and contributions as:

His achievement as legal academic is not merely described but also appraised. It is argued that he must primarily be seen as a Neo-Calvinist legal philosopher in the Kuyperian tradition. His work as one of three foremost academic exponents of the idea and practice of human rights in South Africa is all the more remarkable because his initial ideas were developed in an environment not particularly conducive to an endecvour of this kind.

As scholar of Private Law his main contribution has been the development of the theory of subjective rights in Private Law (and in a purist vein). He is, however, criticised for a paucity of reflection on the development of a similar theory in Public Law. 


\section{1. inleidend: die verdienstes en tekortkominge van hierdie kritiese waardering}

Dit is makliker om 'n gewaardeerde leermeester, kollega en vriend te huldig as om hom/haar te kritiseer. Dít verklaar die potensiële tekortkominge in hierdie kritiese waardering, komende van 'n protégé, kollega en vriend. Die potensiële verdienstes daarvan as waardering moet egter ook nie onderskat word nie want dit kom van iemand wat Johan van der Vyver as regsakademikus, oor meer as drie dekades, goed leer ken en nóú met hom saamgewerk het - en veral wéét dat hy 'n onkritiese waardering van sy werk nie ernstig sal neem nie. Ek het in elk geval té veel agting vir hom om hom met goedkoop lofbetuigings heuning om die mond te probeer smeer.

Sy bydrae tot die regswetenskap word vanuit ses perspektiewe bekyk, naamlik:

- sy alsydigheid;

- sy mentorskap;

- sy bydrae as Neo-Calvinistiese regsfilosoof;

- sy bydrae as herout van menseregte;

- sy bydrae as privaatregsgeleerde en -teoretikus, en

- sy bydrae as publiekregsgeleerde en -teoretikus

Al hierdie perspektiewe bring verdienstes en tekortkominge, sterkpunte en swakpunte, krediete en debiete aan die lig. Uiteindelik hoef die kredietkant egter nie teen die debietkant opgeweeg te word nie. Dit sou té smplisties wees. By die uitsonderlik verdienstelikes onder ons is daar dikwels items, júis aan die debietkant, waarop opvolgers (ofskoon krities) nogtans met vrug kan voortbou. Sulke debietinskrywings word in die loop van die geskiedenis inderdaad bydraes tot die vakgebied. Dieselfde kan nie altyd van alle (byvoorbeeld) tyds- en omstandigheidsgebonde kredietinskrywings gesê word nie.

Johan van der Vyver is 'n uitsonderlik verdienstelike akademikus. Die twee byvoeglike naamwoorde is versigtig gekies, wel wetend dat hy vir sommige omstrede was (en waarskynlik nog is). By sy eie Alma Mater was hy, in die fleur van sy loopbaan, die spreekwoordelik nie-geëerde (en lastige) profeet. Die leidsliede van veral die destydse Bestuur van die $\mathrm{PU}$ vir $\mathrm{CHO}$ wat gemeen het dat hulle hom akademies kon weeg, het nóg die kundigheid nóg die integriteit gehad om dit te doen. Sy vertrek vandaar in 1978, onder politieke druk, het gevolglik sy reputasie as akademikus goed eerder as kwaad gedoen.

Later, aan die Universiteit van die Witwatersrand, is sy werk ook (sagkens gestel) onderwaardeer deur kollegas wat gemeen het dat hulle sy gelykes (of, in hulle oormoed, dalk selfs sy meerderes) is. Daar mag kante aan Johan van der Vyver se styl en persoonlikheid wees wat hom meer omstrede as die "gangbare" (en 
geredeliker konformistiese) "uitsonderlik verdienstelike akademikus" maak. Nogtans speel hy in 'n vakkundige liga wat slegs die voortreflikstes - ten spyte van hulle idiosinkrasieë - haal. Die gerekende Law School aan die Universiteit van Emory het dit - tot hulle eie voordeel - beter as enige inrigting in die niegeëerde profeet se eie land raakgesien.

\section{Die alsydige regsakademikus}

Johan Van der Vyver se (vak-)wetenskaplike oeuvre spreek van sy alsydigheid. Hy het gepubliseer oor onderwerpe so wyd uiteenlopend soos die gatsometer (Van der Vyver, (iv)1 1965a) en die sin-begrip in die Christelike wysbegeerte (Van der Vyver, (iv) 1968d), of die swygreg van kerkleraars (Van der Vyver, (iv) 1977b) en artikel 84 van die Insolvensiewet (Van der Vyver, (iv) 1973c). Dit is egter bloot die punt van die ysberg want sy alsydigheid is, héél eksistensieel, die geskiedenis van 'n regsdosent aan 'n (Suid-) Afrikaanse regsfakulteit (in die vyftiger-, sestigerjare) van wie verwag is om uiteenlopende "vakke in die regte" te doseer. In ' $n$ L.J. du Plessis het dié jong dosent 'n toonaangewende voorganger gehad - iemand wat, as dosent, Latyn, Grieks, Staatsleer, Ekonomie en verskeie regskursusse met ewe veel gemak kon hanteer.

Aan die PU vir CHO was Johan van der Vyver in die eerste plek regsfilosoof en het hy sowat alles wat met die regsfilosofie te make het (op Potchefstroom is dit 'n mondvol!) gedoseer: Regsfilosofie (geskiedenis en sistematiek), Inleiding tot die Regswetenskap (aanvanklik deel van Privaatreg in die eerste jaar), Interfakultêre Wysbegeerte (soos dit destyds geheet het), Regsetiek en Menseregte (oor laasgenoemde in 5 hieronder meer). In Privaatreg was dit onder meer Personereg, Sakereg en Deliktereg. Op 'n stadium moes hy ook wat destyds Bantoereg geheet het (vandag bekend as Inheemse Reg of, op Potchefstroom, Regspluralisme), behartig. Willemien du Plessis se artikel, "The role and future of traditional leaders in South Africa", roep hierdie aspek van Van der Vyver se werk in herinnering.

Sedert sy vertrek vanaf Potchefstroom het hy hom ook in regsgeneeskundige kwessies verdiep. Sy Potchefstroomse studente het hom nooit as volkeregsgeleerde meegemaak nie (behalwe vir sover volkeregtelike aspekte in die kursus Menseregte ter sprake gekom het). Oor die afgelope ongeveer twee dekades het

1 Vir 'n verduideliking van die gebruk van die klein Romeinse syfers in hakies, kyk voetnoot 3 insake die bibliografiese rubrisering van Van der Vyver se wetenskaplike oeuvre. Alle bibliografiese gegewens insake verwysings na Van der Vyver se eie werk is te vind in afdeling 9 van hierdie artikel "Johan van der Vyver se wetenskaplike oeuvre" (i-v). Werke van ander outeurs waama in hierdie artikel verwys word, is opgeneem in $\mathrm{n}$ aparte bibliografie aan die einde van die artikel 
hy hom egter ook op dié terrein ingewerk. Ek is nie daarvan bewus dat hy ooit enige (ander) kursus in die publiekreg gedoseer het nie. Sy belangstelling in menseregte het egter onvermydelik tot etlike publikasies oor veral staatsregtelike onderwerpe aanleiding gegee.

'n Alsydigheid soos pas beskryf, kan natuurlik ook die skyf wees van siniese kommentaar, soos "Jack of all trades and master of none" of, op Afrikaans: "'n Man van twaalf ambagte en dertien ongelukke". So ' $n$ siniese beoordeling is in Johan se geval heeltemal onvanpas. Hy kon miskien groter naam op minder terreine gemaak het - wie weet? Feit is egter dat op 'n kritieke moment in sy loopbaan van hom verwag is om 'n wye verskeidenheid kursusse te doseer. Hoe dan gemaak? Sekere van dié kursusse dalk so 'n bietjie afskeep en probeer om op lieflingsgebiede uit te styg? Nie Johan van der Vyver nie! Sy publikasie-oeuvre is 'n spieëlbeeld van sy doseer-oeuvre. Daarmee stel hy 'n navolgenswaardige voorbeeld: 'n dosent wat in 'n bepaalde kursus klasgee, dra ook die verantwoordelikheid om op dié betrokke vakgebied te publiseer.

In sy alsydigheid is Van der Vyver nietemin primêr 'n regsfilosoof met 'n eie styl. In my bydrae elders in hierdie nommer ("Die sakelys vir wetsteksvertolking en die epog van konstitusionalisme in Suid-Afrika") beskryf ek hom as 'n regsfilosoof wat regsfilosofie "prakties" en werklikheidsbetrokke bedryf. Hy put voorbeelde vir regsfilosofiese analise uit die verskeidenheid vakterreine waarmee hy goed vertroud is. Sy alsydigheid is met ander woorde 'n sine qua non vir sy besondere manier van regsfilosoof wees.

Hierdie alsydigheid verklaar die uiteenlopendheid van die bydraes in hierdie huldigingsnommer. Perspektiewe in enkele van die bydraes kom onvermydelik neer op kritiek van bepaalde fasette van Van der Vyver se werk. Dié bydraes, komende van oudstudente, is nietemin waarderend: terreine waarmee die leermeester hulle aanvanklik op 'n voortreflike wyse vertroud gemaak het, word deur die skrywers krities (verder) verken.

\section{Die mentor}

'n Fassinerende verskynsel in die akademie is hoedat die protégé-navolgers en -opvolgers van voortreflike navorsers hulle as't ware gedronge voel om die werk van die mentor voort te sit. Dit is inderdaad 'n geval van voorbeelde wat veel sterker trek as wat woorde wek. 'n Mentor-navorser wat self publiseer, inspireer veel meer navorsingsbydraes as 'n akademiese burokraat wat deklameer dat hy of sy sus of soveel tydskrifartikels per jaar van (jonger) kollegas verwag. Johan van der Vyver is en was 'n navorsingsinspirerende mentor by uitnemendheid. Wie aldus inspireer, moet egter ook bereid wees om te perspireer: mentorskap is harde werk. Die mentor is die een wat deur die eerste publikasiepogings van protégés moet worstel, wat later in die skryf van verhandelinge en/of proefskrifte geduldig 
leiding moet gee, wat daarna verdere publikasiepogings as aktiewe deelnemer moet meemaak (en aanmoedig) en wat, les bes, 'n standhoudende bron van referensies en getuigskrifte word. Ek beskryf hierdie modelmentor met Johan van der Vyver in gedagte. Ekself dink aan hom as 'n leermeester by wie ek baie kon leer maar veral as 'n gespreksgenoot wat vir my beweegruimte tot kritiese diskoers kon skep. In die destydse tweeman Departement Regsfilosofie op Potchefstroom het hy my, 'n kollega anderhalwe dekade sy junior, nooit as ondergeskikte behandel nie maar uit die staanspoor as 'n volwaardige vennoot respekteer. Dít was ook deur die jare die ervaring van baie ander jonger kollegas vir wie sy hulp, raad en aanmoediging baie beteken het. En dit was nie beperk tot diegene wat formeel onder sy leiding gewerk of gestudeer het nie. Hoe omstrede hy ook al onder sommige van sy tydgenootlike eweknieë was, het hy nog altyd die grootste agting by en waardering van erkentlike jonger kollegas geniet.

As promotor het hy sy studente vrye teuels gegee - miskien te veel. Vandag weet ek dat 'n mens nie (soos wat Johan my toegelaat het) 'n proefskrif van 867 bladsye behoort te skryf nie (vgl. hieronder Du Plessis, 1978). Wanneer ek standpunte ingeneem het waarvan ek geweet het hy sou verskil en ek hom sover probeer kry het om met my daaroor te stry, was sy reaksie meesal: "'n Eie standpunt is jou goeie reg." Miskien moet 'n mens hierdie instelling verstaan teen die agtergrond van sy eie doktorale promosiegeskiedenis - met 'n proefskrif oor menseregte, 1277 bladsye in omvang (Van der Vyver, (i) 1973). Hyself het nooit 'n doktorale promotor gehad wat 'n mens 'n "mentor" in die ware sin van die woord sou kon noem nie. Hy het sy studie onder prof. H.L. Swanepoel begin oor 'n onderwerp wat dié betrokke promotor waarskynlik nie besonderlik geval het nie - en waarvan hy vakkundig ook nie 'n meester was nie. Die studie is uiteindelik onder 'n promotor, met 'n ongeveer soortgelyke instelling en graad van kundigheid, voltooi. Daar is dus rede om te vermoed dat Van der Vyver in sy eie doktorale studie nie baie kundig-krities begelei is nie. 'n Kolossale, konkordansie-agtige proefskrif oor menseregte in die Suid-Afrika van die vroeë sewentigerjare, was miskien nie sonder meriete nie. Dit het inligting oor 'n toentertyd onbekende onderwerp met Van der Vyveriaanse deeglikheid en gesistematiseerdheid gedokumenteer. Proefskrifdissipline bly nietemin 'n deug wat 'n promotor by 'n kandidaat behoort in te skerp - 'n waarheid wat geen promotor ooit by Johan van der Vyver sélf tuisgebring het nie.

Die volgende proefskrifte en verhandelinge is deur nagraadse studente onder sy leiding voltooi: ${ }^{2}$

2 Die betrokke proefskrifte en verhandelinge word chronologies gelys. 


\section{LL.D.-proefskrifte waarvoor hy promotor was}

FOURIE, D.J. 1973. Die Nederduitse Gereformeerde Kerk as regspersoon in die Suid-Afrikaanse privaatreg. Potchefstroom : PU vir CHO.

NEL, F.C. 1974. Die getuie-eed. Potchefstroom : PU vir CHO.

DAVIDTSZ, G.J. 1976. Animus iniuriandi as vereiste vir aanspreeklikheid op grond van privaatregtelike laster. Potchefstroom : $\mathrm{PU}$ vir $\mathrm{CHO}$

VENTER, F. 1978. Die Suid-Afrikaanse bantoestaatsreg. Potchefstroom : PU vir $\mathrm{CHO}$.

DU PLESSIS, L.M. 1978. Die juridiese relevansie van Christelike geregtigheid. Potchefstroom : PU vir $\mathrm{CHO}$

RAMSDEN, H.T. 1985. The status, powers and duties of the Rand Water Board: A legal historical analysis. Johannesburg : Universiteit van die Witwatersrand.

HEYNS, C.H.A. 1992. A jurisprudential analysis of civil disobedience in South Africa. Johannesburg : Universiteit van die Witwatersrand.

\section{LL.D.-proefskrif waarvoor hy medepromotor was}

VAN ZYL, D.H. 1989. Justice and equity in Cicero. Bloemfontein : Universiteit van die Oranje-Vrystaat.

\section{LL.M.-verhandelinge waarvoor hy studieleier was}

SWANEPOEL, D.J. 1977. Die erkenning en toepassing van die bogadl-gebruik by sekere Tswanastamme in die Suid-Afrikaanse reg. Potchefstroom : PU vir $\mathrm{CHO}$.

MADUNA, P.M. 1992. Judicial control of executive and legislative powers of government. Johannesburg : Universiteit van die Witwatersrand.

\section{Die Neo-Calvinistiese regsfilosoof}

Soos voorheen gesuggereer, is en was Johan van der Vyver primêr regsfilosoof en (moet 'n mens byvoeg) héél uitgesproke en onomwonde Calvinistiese regsfilosoof. Sy studente op Potchefstroom het hom leer ken as die dosent wat jou, met die intrapslag, in die geheimenisse (en juridiese gebruikswaarde) van Herman Dooyeweerd se Wysbegeerte van die Wetsidee probeer inlei het (tekenend hiervan is Van Zyl \& Van der Vyver, 1982:15-165 - (ii) in die bibliografie). Dié betrokke filosofie is ' $n$ mylpaal op die pad van Kuyperiaanse Calvinisme, soms ook Neo-Calvinisme genoem. Dit is 'n Calvinisme wat doelbewus die grense van 
gereformeerde teologie probeer oorstyg - 'n "sekulêre" Calvinisme byna wat Christelike geloofsoortuigings in 'n bepaalde religieuse tradisie, vir vakterreine anders as die teologie en vir lewensdimensies meer as die "geestelike", relevant probeer maak. John Witte, Jr. in sy bydrae "The biography and biology of liberty: Abraham Kuyper and the American experiment" vat enkele van die kenmerke van dié betrokke variasie op die Calvinistiese tema goed raak, juis deur dit met Noord-Amerikaanse Puritanisme te kontrasteer.

Deur die Wysbegeerte van die Wetsidee as rigsnoer vir sy beoefening van die regswetenskap te gebruik, sit Johan van der Vyver die werk van sy kleurryke (en ewe omstrede) voorganger op Potchefstroom, L.J. du Plessis, voort (vgl. oor laasgenoemde L.M. du Plessis, 1981). Van der Vyver beskik oor die sonderlinge vermoë om hierdie filosofie tot essensies te reduseer en tot 'n bruikbare instrument vir (selfs) regstudente te vereenvoudig. (Dieselfde kan terloops nie van L.J. du Plessis gesê word nie!) Dooyeweerdiaanse fynproewers kan (tereg) kla dat Van der Vyver die grootmeester se werk té veel oorvereenvoudig (en sekere belangrike kwessies nie eens te berde bring nie). Dit sê egter iets oor Johan se styl as "praktiese" regsfilosoof: vir hóm is die Dooyeweerdiaanse modaliteiteleer met gebruikswaarde in en vir die regswetenskap die uitgangspunt. Die kenteoretiese voorvrae van hierdie filosofie en die daaruit voortspruitende transendentale probleemvrae, asook Dooyeweerd se hoogs "metafisiese" filosofie oor transendentale grondideë, is kwessies wat Johan aan die nuuskierigheid van oorywerige doktorale studente sou oorlaat (vgl. byvoorbeeld Du Plessis, 1978:484504).

Dikwels het hy hom op "die Calvinisme" beroep, ter ondersteuning van standpunte (gewoonlik krities teenoor die apartheidsregime) (vgl. byvoorbeeld Van der Vyver, (ii) 1975:13-16; 1976:51-56 en (iv) 1980c.:280-284). 'n Goeie voorbeeld van uitgesproke verset teen die onreg in die Suid-Afrikaanse samelewing, uit "Calvinistiese" oogpunt, is sy lesing voor die opspraakwekkende kongres van die Afrikaanse Calvinistiese Beweging in Oktober 1976 (Van der Vyver, (v) 1977). Hierdie kritiese Calvinisme (Venter et al., 1990:92-93; kyk ook 7 hieronder) het interessante effekte in apartheid-Suid-Afrika gehad:

- Dit het "etniese" Afrikaner-ondersteuners van apartheid, wat "Calvinisme" as noodsaaklike deel van hulle geestesmondering beskou het, of tot nadenke of tot woede gestem.

- Dit het aan 'n (óór-)heersende, Christelik-nasionale, Afrikaner-Calvinisme onverdiende en (met Van der Vyver se intensies in gedagte ook) onbedoelde geloofwaardigheid gegee. "Dié Calvinisme" in die Suid-Afrika waaroor Van der Vyver geskryf het, was 'n oorwegend burgerlike godsdiens wat die hande van die moeë Moses van apartheid orent help hou het. Van der Vyver se Calvinisme was 'n idealistiese (en toentertyd onwelkome) korrektief - 'n 
randperspektief, van goedkeuring deur toonaangewende Calvinistiese leidsliede (ook op Potchefstroom) verstoke.

- Kritiese Calvinisme het die eerlikes (en dus die minderheid) onder agterdogtige liberale, vir wie Calvinisme 'n merkteken van Afrikaneragterlikheid was, eweneens tot nadenke gestem. Veral Van der Vyver se logies-konsekwente aanhang van die "Calvinistiese beginsel" van soewereiniteit in eie kring ) - wat hy reeds relatief vroeg in sy loopbaan met verwysing na die staat-kerkverhouding regswetenskaplik ontgin het (vgl. Van der Vyver, (ii) 1972) - moes nadenkende liberale in Suid-Afrika besonder bekoor het, want dit is ' $n$ ander manier van sê dat die instellings van civil society outonoom (en vry van staatsinmenging) moet (kan) funksioneer. Van der Vyver se gebruik van hierdie "beginsel" as 'n strategie om die absolutisme van die apartheidsregime te ontmasker, is eintlik 'n (onbedoelde?) "ontcalvinisering" van 'n oortuiging wat (na bewering) vanaf die "oorspronklike" Calvyn, via Groen Van Prinsterer en Abraham Kuyper, in die Wysbegeente van die Wetsidee van Dooyeweerd neerslag vind. "Die Calvinisme" en sekulêr-klassieke liberalisme is dit egter wesenlik oor dié leerstuk eens. Soewereiniteit in eie kring is, met ander woorde, ewe goed (Neo-) Calvinisme én klassieke liberalisme. Van der Vyver se konsekwente beroep op soewereiniteit in eie kring verklaar waarskynlik byvoorbeeld sy skeptisisme oor 'n menseregtehandves met derdewerking (vgl. byvoorbeeld Van der Vyver, (iv) 1982b:583): 'n menseregtehandves behoort slegs die staat te bind en nie vir akteurs op (soewerein-in-eie-kring) nie-staatlike terreine allerlei voorskrifte neer te lê nie. Dit is 'n klassiek-liberale (en tegelyk óók konserwatief-modernistiese) siening ingevolge waarvan 'n menseregtehandves feitlik uitsluitlik 'n afweermeganisme teen die misbruik van staatsgesag is.

'n Ander goue draad wat deur Johan van der Vyver se kritiese diskoers oor die regsbestel in (apartheid-) Suid-Afrika loop, is sy aangryping van die Aristoteliese konsep van geregtigheid. Hieroor het hy vir die eerste keer uitvoerig in Koers geskryf (Van der Vyver, (iv) 1962b.). Daarna het hy veral Aristoteles se siening van uitdelende geregtigheid as 'n basis gebruik om kritiese aanvalle op verskillende vorme van diskriminasie, veral rassediskriminasie, in die SuidAfrikaanse bestel te loods (vgl. byvoorbeeld Van der Vyver, (ii) 1976:1-4; (v) 1977:59-63). Dieselfde tema figureer so onlangs soos verlede jaar prominent in sy beoordeling van die gelykheidsklousule in Suid-Afrika se 1996-Grondwet (Van der Vyver, (iv) 1998c:381-385). Hy gee met ander woorde aan die denke van 'n antieke filosoof eietydse relevansie - soos ook Deon van Zyl met sy bydrae in hierdie nommer, "Waarheid, geregtigheid en billikheid in Platoniese perspektief", probeer doen.

As Potchefstroomse Calvinis het Johan van der Vyver ook veel gedoen om die regsdenke van 'n ander groot Potchefstromer, H.G. Stoker (vgl. byvoorbeeld 
Stoker, 1970), op die sakelys van regswetenskaplike besinning te plaas (vgl. Van der Vyver, (i) 1973:7-9, 431-435 en 1217-1218; (ii) 1975:14-15 en (iv) 1994f.).

In 'n postmoderne leefwêreld, op die vooraand van 'n nuwe millennium, kan 'n mens tereg vra of Van der Vyver se omarming van 'n Dooyeweerd, 'n Aristoteles en 'n Stoker nog van enige besondere betekenis is. Aristoteles kon kwalik voorsien dat, bykans drie en twintig eeue na sy dood, die konsep van substantiewe gelykheid (wat radikale andersheid honoreer) sy eie, kunstig beredeneerde (en op "meriete" gebaseerde) konsep van formele gelykheid sou bevraagteken. Herman Dooyeweerd was - pretensies tot die teendeel ten spyt 'n rasionalistiese modernis, in die tradisie van 'n Kant, 'n Hegel en 'n Husserl, in dieselfde mate as wat hy kosjer-Calvinis was. En Stoker, die Afrikanemasionalis, wat vele "mooi dinge" oor geregtigheid en menseregte te sê gehad het, het waarskynlik nie in sy wildste verbeeldingsvlugte 'n "nuwe" Suid-Afrika met 'n "swart meerderheidsregering" sien aanbreek nie. Johan van der Vyver het nietemin (onvoorsien en onbedoeld miskien) die sterkpunte van hierdie "onvolkome" tradisies by studente ingeprent op 'n manier wat hulle die vrymoedigheid sal kan gee om die uitdagings van 'n postmoderne leefwêreld te kan aandurf. Latere "afwykings" van die styl en benadering van die leermeester (waarvan enkele bydraes in hierdie nommer voorbeelde is) is, só gesien, dus beklemtonings van die grootheid eerder as die verbygaande aard van sy werk. Daar is by sy werk aanknoping te vind vir die ontwikkeling van (sê maar) 'n vroeg een en twintig-eeuse postliberalisme en postcalvinisme. 'n Mens moet ook onthou dat die Regsfilosofie wat in die vyftiger-, sestiger- en selfs vroeë sewentigerjare op Potchefstroom beskikbaar was, beter was as enigiets anders wat 'n mens op hierdie vakterrein by ander Suid-Afrikaanse regsfakulteite, veral aan Afrikaanse universiteite, sou kry. Regsfilosofie het elders gewoon nie as 'n baie sigbare vakgebied gefigureer nie (vgl. byvoorbeeld Dugard, 1971:186).

\section{Die menseregte-herout}

By geleentheid het ek (regs-)akademici se deurslaggewende bydrae tot die vestiging en groei van 'n menseregtekultuur in Suid-Afrika só beskryf (Du Plessis, 1996:225):

Many human rights initiatives in South Africa have been academically driven or originated from the efforts of academics. Of all the branches of the legal profession the academic branch has undoubtedly shown the keenest alertness to the ideals of constitutionalism. The forces mostly contributing to the advent of South Africa's justiciable Constitution with its Bill of Rights have been the struggle and academic endeavour. The struggle provided the drive, the academic world the intellectual discipline, to cast the achievements of the struggle in a constitutionally serviceable mould. 
Ek het veral aan figure soos Johan van der Vyver, John Dugard en wyle Tony Mathews gedink toe ek dít geskryf het. Dit is nie nodig om hulle met 'n omhaal van woorde as voorste akademiese menseregte-eksponente te huldig nie. Die geskiedenis sélf doen dit. Twee van hulle (Van der Vyver en Dugard) kan beleef hoedat 'n ideaal waarvoor hulle hul, dikwels teen aansienlike teenstand in, beywer het, praktyk word. Dit is 'n voorreg sonder weerga!

Die interessante is dat die gemelde drie figure uit taamlik uiteenlopende akademiese en geestesagtergronde kom. Mathews is 'n deur en deur liberale eksponent van menseregte wat die apartheidsbestel hoofsaaklik uit 'n rule of lawperspektief gekritiseer het (vgl. Mathews, 1971 en 1986). Dugard is ook oorwegend liberaal in sy aanslag, maar as Stellenbosse oudstudent het hy goeie insig in en begrip vir die puristiese regstradisie in Suid-Afrika (waaroor in 6 en 7 hieronder meer) (vgl. Dugard 1971 en 1978). Van der Vyver was die Calvinistiese stem des roepende in die woestyn wat met sy toonaangewende publikasies oor menseregte, óók in Afrikaans (Van der Vyver, (i) 1973; (ii) 1974, 1975, 1976 - om maar net na monografieë te verwys), baie gedoen het om 'n tradisioneel konserwatiewer seksie van die wit Suid-Afrikaanse gemeenskap tot besinning oor menseregte te bring (en dikwels te skok). Parogiaal was sy bydrae egter nie en hy geniet wye internasionale erkenning vir sy werk. Hy is byvoorbeeld deur die hoogs aangeskrewe International Institute of Human Rights in Strasbourg genooi om 'n reeks lesings oor algemene menseregteteorieë aan te bied (Van der Vyver, (v) 1976) - na my wete die eerste Suid-Afrikaner om dié eer te beurt te val. Hy was ook die inisieerder van en 'n dryfkrag agter die First International Conference on Human Rights in South Africa wat vanaf 22 tot 26 Januarie 1979 in Kaapstad gehou is (vgl. Forsyth \& Schiller eds., 1979). Die organisasie Regslui vir Menseregte/Lawyers for Human Rights is uiteindelik uit hierdie konferensie gebore. Potchefstroom kan voorts tereg daarop trots wees dat die Regsfakulteit aldaar, op inisiatief van Johan van der Vyver, in die vroeë sewentigerjare die eerste in die land geword het om 'n kursus in Menseregte op LL.B.-vlak aan te bied - vóór enige van selfs die liberale fakulteite en taamlik lank voordat dit akademies hoogmode geword het!

Interessant is dat, in Van der Vyver se vroeere bydraes, daar dikwels 'n skeptiese ondertoon oor die humanistiese genealogie van die leerstuk van menseregte te bespeur is (vgl. byvoorbeeld Van der Vyver, (i) 1973:1207-1250 en (ii) 1975:1). Sy proefskrif sluit hy byvoorbeeld met die volgende woorde af (Van der Vyver, (i) 1973:1250):

Hoe ons ... ook al van die premisse en besondere uitlopers van die tradisionele menseregteteorie mag verskil, moet daarby steeds in gedagte gehou word dat die leerstuk van menseregte die aandag gevestig het en gevestig hou op etiesgefundeerde prinsipes wat in die reg verwerklik behoort te word. Solank ons nie by die humanisme bly vassteek en die bedoelde prinsipes uit die wissel- 
Lourens du Plessis

vallige voorskrifte van die menslike Rede probeer abstraheer nie, kan hierdie bydrae van die leerstuk van menseregte vrugbaar omgebuig word om ons opnuut op soek te laat gaan na daardie bo-willekeurige eties- en pistiesgefundeerde regsbeginsels wat in die skeppingsorde gefundeer is en wat as Sollensprinzip vir elke positiewe regstelsel deur regsvormers voor oë gehou moet word - dat die mens sy roeping ook op juridiese gebied sal volvoer tot Sy eer, uit Wie, deur Wie en tot Wie alle dinge is.

Dit is duidelik die Neo-Calvinistiese Dooyeweerdiaan hier aan die woord - in gesprek met skeptiese geloofsgenote, baie waarvan destyds geglo het dat die mens nie regte het nie (net pligte) en dat menseregte, soos die regterlike toetsingskompetensie vir oom Paul Kruger (Klug, 1997:193), 'n uitvindsel van die Duiwel is (vgl. ook Potgieter, 1989 veral 396-397 en die reaksie van Du Plessis, 1990). Elders skryf Van der Vyver ((ii) 1975:1):

Vanuit 'n nie-humanistiese gesigspunt is 'n mens se eerste inklinasie ... om die idee van natuurlike menseregte as humanistiese onsin te verwerp ... Maar nou is dit so dat die idee van natuurlike menseregte hom nie net in sy humanistiese gedaante aan ons opdring nie maar ook in ander wysgerige stelsels - sy dit dan in gewysigde vorm - burgerreg verkry het. Aldus tref 'n mens ook menseregteteorieë in die modeme Rooms-Katolieke en Calvinistiese wysbegeerte aan.

Oor die Calvinistiese benadering tot menseregte laat hy hom gematig en "opbouend" krities uit (Van der Vyver, (ii) 1975:15). "Daar moet ook wel nog aan die Calvinistiese menseregteteorieë gebeitel en geskaaf word", sê hy, en verduidelik dan geduldig in watter opsigte hy meen Herman Dooyeweerd, dié se getroue navolger, H.J. van Eikema Hommes en uiteindelik ook H.G. Stoker sulke beitel- en skaafwerk aan hulle teorieë kan doen. Stoker se bereidwilligheid om, so vroeg soos 1965, hoewel "kursories", (nogtans) Calvinisties-filosofies oor "duiwelsgoed" soos menseregte te besin, is waarskynlik 'n rede waarom Van der Vyver hom so sterk tot die regsdenke van hierdie filosofiese leermeester van hom aangetrokke voel (vgl. Stoker, 1967:113-123; vgl. ook Van der Vyver (iv), 1994f se waardering van Stoker se regsdenke).

\section{Die privaatregsgeleerde en -teoretikus}

Op privaatregsterrein is Johan van der Vyver veral bekend vir sy bydrae tot die ontwikkeling en vestiging van die teorie van subjektiewe regte as modus operandi om subjektiewe reghebbendheid en die daaruit resulterende regsverhoudings in die privaatreg te verklaar (vgl. byvoorbeeld Van der Vyver \& Joubert, 1991:1-31). Sy bydrae in die W.A. Joubert-gedenkbundel (Van der Vyver, (iii) 1988b.) is 'n besonder nuttige uiteensetting van die historiese oorsprong, groei, ontwikkeling en gebruikswaarde van dié teorie. Hy het, waarskynlik méér as enige ander Suid-Afrikaanse juris, 'n teoretiese model in die privaatreg wat W.A. Joubert (1958) (onder inspirasie van Dooyeweerd) 
aangevoor het, sinvol uitgebou en "voltooi". Hy inkorporeer prakties nuttige onderskeidingskriteria in dié teorie, byvoorbeeld 'n werkdadige onderskeid tussen subjektiewe regte, kompetensies en bevoegdhede, om sodoende wollerige persepsies oor die onderskeid tussen my reg as 'n aanspraak op dit of dat, in teenstelling met "my regte" om dit of dat te kan en mag doen, uit die weg te probeer ruim. Kompetensies (behorend tot die domein van dit wat juridies kan) beskryf hy as bemagtigende voorwaardes vir die skep van subjektiewe regte op objekte, uit hoofde waarvan regsubjekte bevoeg is om sus of so met sulke objekte te mag handel. Hierin betoon hy hom, in die tradisie van regwetenskapsbeoefening in Suid-Afrika, as puris.

'n Mens kan lank oor die verskille in benadering tussen sogenaamde puristiese en modenistiese regswetenskapsbeoefening in Suid-Afrika uitwei (vgl. byvoorbeeld Van Blerk, 1984; Venter et al., 1990:81-83; Du Plessis, 1999:59-65). Voor dié versoeking word hier nie geswig nie. Tradisioneel (tot wie weet presies wanneer) was daar die persepsie dat regsgeleerdes by Afrikaanstalige regsfakulteite in Suid-Afrika 'n oorwegend Romeins-Hollandsregtelik-georiënteerde beginselbenadering en regsgeleerdes by Engelstalige regsfakulteite 'n oorwegend Engelsregtelik-georiënteerde, kasuïstiese benadering tot regswetenskapsbeoefening daarop nahou. Soos enige persepsie, is en was ook dié een nie onberispelik akkuraat nie al het dit 'n element van waarheid gehad. Dít is naamlik so dat die hibriede Suid-Afrikaanse regstradisie, histories gesien, in sigself elemente van sowel 'n Europees-vastelandse beginselbenadering as 'n Engelsregtelik-kasuistiese common law-benadenng huisves (en dit is inderdaad uiteenlopende en soms selfs weersprekende benaderings). Die fassinerende les wat so 'n tradisie 'n mens leer, is dat dié twee benaderings nie wedersyds uitsluitend hoef te wees nie - en dat jy dus versigtig moet wees om finale uitsprake te maak oor die vraag of die een of die ander by toonaangewende regsgeleerdes in Suid-Afrika voorrang geniet.

Die manier waarop Van der Vyver met die teorie van subjektiewe regte omgaan, is onmiskenbaar puristies-beginselmatig. Die puristiese benadering beskryf ek elders samevatted só (Du Plessis, 1999:64):

Die puriste se benadering tot die reg as 'n beginselbenadering, is in 'n sin eenvoudig, want dit is aantreklik-sistematies - dit is 'logies' en tegelyk ook intellektueel robuus. Die konsekwentheid daarvan is aantreklik. Dit vind sterk aanklank by die Europees-Vastelandse (veral die Duitse en Nederlandse) akademiese tradisie, waarmee die meeste puriste noue kontak het.

Van der Vyver het trouens die privaatregswetenskap beoefen op 'n manier baie soortgelyk aan dié van baie ander van sy kollegas aan veral (maar nie uitsluitlik nie) Afrikaanse regsfakulteite. Christa Rautenbach se bydrae in hierdie nommer, "Die pactum successorium: stiefkind van die Suid-Afrikaanse reg", is (ofskoon dit handel oor 'n onderwerp op 'n vakterrein wat Johan van der Vyver nooit self 
betree het nie) 'n voorbeeld van hierdie styl van regswetenskapsbeoefening. Die vakterrein word krities vanuit die puristiese paradigma self verken, uitgebou en "gekorrigeer". Let daarop dat dit 'n oorvereenvoudiging is om te sê dat purisme 'n aanhang van die "suiwer" Romeins-Hollandse reg impliseer en modemisme 'n groter toegeneentheid jeens die Engelse reg beteken. Dit is nie lojaliteite wat hier onderskeidend is nie maar die modus operandi oftewel metodes wat in albei gevalle gevolg word.

'n Oorwegend puristiese Van der Vyver is, net soos sy voorganger L.J. du Plessis (vgl. L.M. du Plessis, 1981:38-44), heel geneë om aanknopingspunte by meer kasuistiese benaderings te soek. Gegewe sy teoretiese model, is die pleeg van 'n delik vir Van der Vyver byvoorbeeld gelyk aan die skending van 'n subjektiewe reg. Hy aanvaar nietemin dat 'n mens dit ook, soos toonaangewende, niepuristiese skrywers oor die deliktereg (en met name McKerron), as die nienakoming van 'n duty kan beskou, omdat duties per slot van sake die keersy van subjektiewe reghebbendheid is (vgl. byvoorbeeld Van der Vyver, (iv) 1969). Charles J. Reid se ongewone spel met Van der Vyver se subjektiewe regtemodel elders in hierdie nommer ("Van der Vyver's analysis of rights: A case study drawn from thirteenth-century canon law"), wys dat daar 'n inherente plastisiteit in Van der Vyver se hantering van dié model is.

Van der Vyver se subjektiewe regteteorie is al immanent-krities geweeg deur sommige van sy oudstudente vir wie diè teorie akademiese moedersmelk was. Immanente kritiek is 'n term wat Van der Vyver self graag gebriik (vgl. byvoorbeeld Van der Vyver, (i) 1973:1208-1209). Dit is kritiek op 'n standpunt of benadering van iemand wat die uitgangspunte van daardie benadering ernstig neem en dan inkonsekwenthede in andere se uitwerk daarvan uitwys. A.J. van der Walt (1986) bevraagteken byvoorbeeld binne Van der Vyver se eie sisteem, sy "ontdekking" van relatiewe saaklike regte. Ekself kritiseer Van der Vyver omdat hy die moontlikheid van 'n onderskeid tussen absolute en relatiewe subjektiewe regte, té konsekwent en selfs rigied afwys terwyl 'n sekere kategorie regte in sekere omstandighede tog 'n duidelik aantoonbare, sterker werking as ander het (Du Plessis, 1999:151-154).

Daar is ook transendentale kritiek op die subjektiewe regteteorie te lewer, dit wil sê kritiek wat die uitgangspunte waarop dié teorie berus, bevraagteken (Van der Vyver, (i) 1973:1219; Venter et al., 1990:77). Van der Walt bevraagteken in sy 1990-artikel byvoorbeeld Van der Vyver se aanname dat elke privaatregtelike remedie die bestaan van 'n subjektiewe reg wat deur die remedie beskerm (kan) word, voorveronderstel. Die mandement van spolie is 'n besitsbeskermingsremedie wat ook tot die onregmatige besitter se beskikking is. Vir Van der Walt is dit problematies om te sê dat so 'n besitter 'n subjektiewe reg het op die saak wat hy of sy onregmatig besit. Hierdie kritiek is grenskritiek in 'n postmoderne 
idioom wat Van der Walt in 'n nog latere artikel (Van der Walt, 1995) vollediger uitwerk.

'n Mens moet onthou dat die subjektiewe regteteorie hoofsaaklik geskik is om privaatregsverhoudings in 'n bourgeois kapitalistiese samelewing te verklaar en dit is dus nie so veelseggend in ' $n$ samelewing waar ' $n$ chronies oneweredige verspreiding van materiële middele reggestel moet word nie. Hieroor wil ek hier nie uitvoerig uitwei nie behalwe om te sê dat konstitusionalisme dit duidelik op die agenda van juridiese refleksie in Suid-Afrika geplaas het want ' $n$ toenemende "publiekwording" van baie tradisioneel privaatregtelike subjektiewe regte (en veral ook eiendomsreg) het daardeur onvermydelik geword. Sekere van Van der Vyver se bydraes antisipeer hierdie ontwikkeling (Van der Vyver, (iii) 1989a en 1996b). André van der Walt se bydrae in hierdie nommer ("Property rights and hierarchies of power: an evaluation of land reform policy in South Africa") staan egter volledig in die gees van hierdie nuwe ontwikkeling. Hierby sluit ook die bydrae van Theo Scheepers ("The legal duty of local government to facilitate development") aan, al het dit nie 'n spesifiek privaatregtelike fokus nie. In dieselfde kategorie val ook Johan Kruger se "Provinsiale staatsgrond: Lank lewe die tussentydse Grondwet", ofskoon dié bydrae, selfs nog meer as dié van Scheepers, uitgesproke publiekregtelik is.

\section{Die publiekregsgeleerde en -teoretikus}

In sy kritiek op die juridiese manifesterings van apartheid in Suid-Afrika, maak John Dugard (1971:197-198) 'n interessante strategiese skuif. Hy skets naamlik "ons Romeins-Hollandse regserfenis" soos wat regspuriste in Suid-Afrika dit veelal sou noem, as 'n menseregtevriendelike tradisie. In 'n regsbestel waar dié tradisie intakt sou bly, sou rasdiskriminerende apartheid met sy sekurokratiese ondersteuningsmeganismes, volgens Dugard, regtens nie geoorloof wees nie. Hy gee 'n aantal praktiese voorbeelde wat die bewering staaf. Anders as baie ander kritici van die destydse bestel, wend Dugard hom dus nie slegs tot AngloAmerikaanse bronne vir skietgoed teen die regsmanifestasies van apartheid nie. Só plaas hy die publiekregs- en in sonderheid menseregtedebat op 'n regspuristiese besinningsagenda. Met sy kritiek op die oorwegend regspositivistiese inslag van gangbare regs- en regswetenskapsbeoefening in Suid-Afrika, is Dugard voorts herout van 'n nuwe benadering in die Suid-Afrikaanse regsdenke wat die modernisme-purisme-dichotomie relativeer - en oorstyg (Venter et al., 1990:8498; Du Plessis, 1999:64-69). ('n Mens moet billikheidshalwe byvoeg dat L.J. du Plessis Dugard hierin 'n dekade of wat vooruit was - vgl. L.M. du Plessis, 1981:38-44. En onthou: Johan van der Vyver was 'n student van Wikus du Plessis.)

Met hierdie enigermate uitvoerige inleiding probeer ek die opkoms skets van 'n benadering tot regsdenke waarvan Johan van der Vyver óók deel was. Niemand 
het tot op hede 'n oorkoepelende naam daarvoor probeer gee nie. Die eksponente daarvan het almal egter 'n kritiese houding jeens die gepretendeerde waardeneutraliteit van die verskillende manifesterings van regspositivisme in gemeen. Voorts is hulle eie denke oorwegend krities en onder hulle tel van die felste teenstanders van verskillende fasette van 'n apartheid-Suid-Afrika in sy regsgewaad. Dugard kritiseer byvoorbeeld die werk van die regbank onder apartheid indringend. Ander skrywers, soos David Dyzenhaus (1982 en 1983), John Hund en Van der Merwe (1986) asook Hugh Corder en Dennis Davis (1988), bepleit, vanuit maatskappykritiese gesigspunte, 'n konteksgevoelige beoefening van akademiese regsgeleerdheid. Onder hierdie kritiese stemme op regsgebied tel ook diê van 'n Wikus du Plessis en veral 'n Johan van der Vyver. Dié kritiese Calvinisme is ongelukkig egter nie altyd die klokhelder stem van F.M. nie - veral nie waar dit, soos met die subjektiewe regteteorie in die privaatreg (kyk 6 hierbo), hoorbaar behoort te gewees het in die ontwikkeling van 'n publiekregtelike teorie oor regsubjektiwiteit nie. Van al die fasette van sy regswetenskaplike bydrae, is die alsydige Johan van der Vyver se bydrae (maar ook sy versuim) as publiekregsgeleerde en -teoretikus, die oopste vir knitiek. Dit sluit egter nie sy werk op volkeregtelike gebied in nie. (Die bydrae van Harold J. Berman oor "World law" is terloops in hierdie nommer opgeneem om aan hierdie faset van Van der Vyver se werk die nodige erkenning te gee.)

Ek wil my kritiese houding oor Van der Vyver se werk op die publiekregsterrein só verduidelik:

Elders in hierdie nommer skryf Francois Venter ("Regte, gesag en waardes"), self 'n Van der Vyver-doktorant, oor 'n onderwerp waaroor hy hom lank reeds kwel, naamlik die ontwikkeling van 'n publiekregtelike subjektiewe regteteorie (vgl. byvoorbeeld Venter, 1985 en 1991). Venter is sterk aangespreek deur die ordelikheid en gesistematiseerdheid van die privaatregtelike teorie en hy wil dit dus in 'n publiekregtelike toonaard transponeer. Daar is andere, soos Marinus Wiechers (1988), wat krities is oor sulke pogings maar die alternatiewe wat hy te bied het, kan beslis nie Venter se behoefte aan orde en sisteem bevredig nie

Venter (1985:151) gee, op sterkte van sy publiekregtelik verwerkte weergawe van die privaatregtelike teorie, te kenne dat die staat ook publiekregtelike reghebbende vis à vis die onderdaan kan wees. Van der Vyver ((iii)1988b:208) sê dat dit 'n "preposterous idea" is. Dit is sterk taal komend van 'n menseregtekenner vir wie so 'n opvatting waarskynlik heiligskennis is. Wat Van der Vyver egter versuim om toe te gee, is dat so 'n uitspraak ' $n$ logiese konsekwensie van sy eie subjektiewe regteteorie in 'n publiekregtelike baadjie is - en dus eintlik op sy eie onbetaalde rekening staan! Hy maak gewag van die feit dat daar in SuidAfrika nog nie juis veel gedoen is aan teoretiese besinning oor publiekregtelike regsubjektiwiteit nie (en dat met die laaste woord daaroor ook nog nie gespreek is nie) (Van der Vyver, (iii) 1988b:208). Wat hy weer eens egter verswyg, is dat 
indien daar een teoretikus in Suid-Afrika is wat op hierdie terrein 'n waardevolle bydrae sou kon lewer, dit hyself is! En dit is nie 'n kwessie dat hy net nog net nie daarby kon uitkom nie. Hy het nooit werklik daarmee begin nie. In die slothoofstuk van sy proefskrif, getiteld Samevatting en kritiek, sou 'n mens byvoorbeeld verwag dat hy die aangeleentheid moes aanroer. Wat hy eerder doen, is egter om vanaf filosofiese kritiek op verskillende variasies van die leerstuk van menseregte, gladweg oor te skakel na 'n volgende versnelling van louter privaatregtelike subjektiewe regte (Van der Vyver, (i) 1973:1238-1250).

Oor die redes vir hierdie versuim kan ek nie afdoende oordeel nie. Dit het miskien te doen met die feit dat Van der Vyver nooit dosent in 'n volbloed publiekregtelike dissipline was nie. Sy doseerwerk het immers baie van sy nadenke en navorsing geïnspireer (kyk 2 hierbo). Dit kan ook wees dat hy, in sy vormingsjare as doktorale student, té veel by slegs die Amerikaners oor menseregte kers opgesteek het. Sowel akademiese regsgeleerdheid as menseregtejurisprudensie in die VSA is nie uitsonderlik bekend vir 'n geordende en sistematiese ontwikkeling van teoretiese konsepte nie. Van der Vyver se kontak met die Vastelandse tradisie van teoretiese besinning oor subjektiewe regte was hoofsaaklik via die Wysbegeerte van die Wetsidee - wat op die privaatreg konsentreer. Oor sy omgaan met die Amerikaners is daar wel 'n lansie vir Van der Vyver te breek. Hy is die een Suid-Afrikaanse regskrywer wat Amerikaanse menseregtejurisprudensie sistematies en logies geordend kan verduidelik - terwyl die stof self dit nie altyd daartoe leen nie (vir 'n uitnemende voorbeeld, kyk Van der Vyver, (ii) 1972:103-127). Of dit vanweë sy purisme of gewoon 'n persoonlike vermoë só is, laat ek daar.

Ek het ten slotte ook probleme met Van der Vyver se manier van wets- en grondwetsvertolking. Miskien opper ek dié kritiek omdat regs- en grondwetsvertolking die afgelope aantal jare die terrein(e) geword het waarop ek die meeste navorsing doen. Ter versagting: my belangstelling hierin is Johan - wat self nooit akademies op hierdie terrein(e) gewerk het nie - se skuld. Hý was die Potchefstroomse dekaan wat my, as mees junior doserende personeellid in die Fakulteit, aangesê het om Uitleg van Wette te doseer omdat nie een van die senior kollegas wou nie. Daarvoor alleen sou ek al my ander bydrae in hierdie nommer, "Die sakelys vir wetsteksvertolking en die epog van konstitusionalisme in SuidAfrika", aan hom kon opdra! Dié bydrae is egter ook bedoel as korrektief op wat ek meen aan Van der Vyver se nadenke oor die rol van die regsvertolker haper.

Met die koms van die nuwe grondwetlike bedeling (en twee agtereenvolgende oppermagtige grondwette) het Van der Vyver hom by verskeie geleenthede oor die vertolking van sekere sleutelbepalings in albei grondwette uitgelaat (vgl. byvoorbeeld Van der Vyver, (iv) 1994e, 1995 en 1998c). Sy vertolkings was baie keer teen die hoofstroom in en omstrede; dog nooit vervelig nie maar altyd vars en nadenke-stimulerend. Met baie daarvan het ek nie saamgestem nie - maar dit 
is vir die kritiek wat ek hier wil lewer, nie ter sake nie. Van der Vyver, weet almal wat hom ken, is ' $n$ individualis en daarby soms so 'n bietjie moedswillig ook. Daarby het hy 'n skerp analitiese oog en 'n byna pynlik korrekte sistematiese vermoë om uiteenlopende teksgedeeltes met mekaar in verband te bring. Sy lesings van wetstekste en veral die grondwetsteks is daarom altyd interessant en besondere bydraes tot vertolkingsdebatte. Maar dit is ook my probleem met Van der Vyver: hy is die een regsgeleerde wat met sy lesings van veral die grondwetsteks, illustreer hoe óóp die betekenis daarvan in werklıkeid is ... en dan steeds 'n verknogtheid aan letterknegtige uitleg, geinspireer deur die droombeeld van duidelike en ondubbelsinnige taal, as evangelie verkondig (en aan dicta uit die regspraak wat met hom hieroor saampraat, onkrities onverdiende legitimiteit gee) (vgl. byvoorbeeld Van der Vyver, (iv) 1995:574-577). As rede vir sy benadering voer hy onder meer aan dat grondwetsvertolking nie maar 'n "everything goes" kan wees nie. Natuurlik nie! As deurwinterde regsfilosoof behoort hy egter te weet dat daar baie geloofwaardiger maniere is om presies "dié punt te stel". 'n Mens hoef nie van taal iets te maak wat dit nie kan wees nie.

Ten slotte is daar, juis in verband met grondwetsvertolking, een kwessie waaroor ekself en ander kollegas al gewonder het. Johan van der Vyver was die advokaat vir die suksesvolle appellante in Government of the Republic of Bophuthatswana and Others $v$ Segale (1990 (1) S.A. 343 (B.A.D.)). In hierdie saak het die hoogste hof in dié destydse "tuisland" bevind dat die "duidelike taal" van 'n gewone parlementswet, 'n algemeen geformuleerde (en dus vaer en dubbelsinniger), regteverskansende bepaling in 'n oppermagtige grondwet kan troef? 'n Mens kan natuurlik nie die "suksesvolle" advokaat in so 'n saak al die belaglikhede wat die hof in sy uitspraak kwytraak, ten laste lê nie. En tog wonder jy: wat op aarde het adv. Van der Vyver in sy betoog kwytgeraak wat die saadjie vir so 'n "preposterous idea" (en daarby ook 'n baie gevaarlike een) by die regter kon plant?

\section{Slotperspektiewe}

Dit dan is, met vele fasette ongelukkig nog onderbelig, 'n akademiese portret van 'n gewaardeerde leermeester, kollega en vriend wat op 21 Februarie 1999 sy vyf en sestigste verjaardag gevier het. Met sy tipiese pittigheid praat Johan, in 'n huldigingsartikel, van een van sy filosofiese leermeesters, H.G. Stoker, wat "of pensionable age" was toe hy "in die fleur van sy bejaardheid" vir die eerste keer 'n eie regsbeskouing ontwikkel het (Van der Vyver, 1994f:403-404). Volgens Suid-Afrikaanse standaarde het Johan ook nou "of pensionable age" geword maar aan sy akademiese uitsette merk 'n mens nog geen teken van selfs 'n fleurige bejaardheid nie. Die élan het nog nie verflou nie, die skerp analises en die onverdrote werkywer is nog daar en selfs die periodieke moedswilligheid wil maar nie gaan lê nie. 
'n Mens kan 'n cliché gebruik en sê dat sonder Johan van der Vyver se akademiese bydrae regsgeleerdheid in Suid-Afrika veel armer sou gewees het. Ek huiwer egter om dit te doen, gewoon omdat ek my hoegenaamd nie die reg en regswetenskap in Suid-Afrika sonder 'n Johan van der Vyver kan indink nie en die cliché dus nie met selfs hipotetiese geloofwaardigheid kan gebruik nie. Soos ander van sy oudstudente wil ek eerder, sonder vrees vir oordrywing, sê dat hy die persoon was wat die meeste invloed op my ontwikkeling as jong regsgeleerde gehad het. Ekself en diesulkes wil hom hiervoor huldig juis deur nie blote napraters van sy standpunte nie, maar navolgers van die voorbeeld wat hy vir ons gestel het, te probeer wees.

\section{Johan van der Vyver se wetenskaplike oeuvre ${ }^{3}$}

Bibliografiese rubrisering van Van der Vyver se wetenskaplike bydraes.

[Uitgeslote populêre artikels in vaktydskrifte en die dagbladpers, boekresensies en 'n lys van ongepubliseerde vakkundige en ander lesings en voordragte.]

\section{(i) LL.D.-proefskrif}

1973. Die juridiese sin van die leerstuk van menseregte. Pretoria : Universiteit van Pretoria.

\section{(ii) Handboeke en ander monografieë}

1972. Die juridiese funksie van staat en kerk: 'n Kritiese analise van die beginsel van soewereiniteit in eie kring. Durban : Butterworths.

1974. Menseregte. Brosjure nr. 6 van die Instituut vir die Bevordering van Calvinisme, Potchefstroom.

1975. Die beskerming van menseregte in Suid-Afrika. Kaapstad/Wynberg/Johannesburg/Durban : Juta. 1976. Seven lectures on human rights. Kaapstad/Wynberg/Johannesburg : Juta.

1982. (met Van Zyl, F.J as mede-outeur). Inleiding tot die regswetenskap. 2de uitg Durban : Butterworths. (lste uitg. 1972.)

1984. Die Grondwet van die Republiek van Suid-Afrika. Johannesburg/Kaapstad : Lex Patria 1988. Reformed Christians and social justice. Sioux Center, lowa : Dordt College Press.

1991. (met Joubert, D.J. as mede-outeur). Persone- en familiereg. 3de uitg. Kaapstad/ Wetton/Johannesburg : Juta. (1ste uitg. 1982, 2de uitg. 1985.)

\section{(iii) Hoofstukke in boeke}

1973. Die Church of England: 'n Kritiese analise van die staatskerkidee. (In Van Rensburg, S.P.J.J., red. Hervormde Teologiese Studies: Studia Theologica Varia, Dictata. Pretoria p. 127-144.)

3 Hierdie lys van Van der Vyver publikasies word onderverdeel in vyf onderafdelings - genommer (i)-(v). Wanneer in die artikel na Van der Vyver se werke verwys word, word die nommer van die betrokke onderafdeling ook gesitcer (bv. Van der Vyver (ii) 1972) om opsporing in die lys wat volg te vergemaklik. 
1975a. Die juridiese funksie van staat en kerk. 'n Kritiese analise van die beginsel van soewereiniteit in eie kring. (In Ses inougurele redes (1970-1973) van die Fakulteit Regte van die Potchefstroomse Universiteit vir Christelike Hoer Onderwys. Potchefstroom. p. 126.)

1975b. The unruly horse: Reflections on the rule of law. (In Social theory and practice: Crosscuts and perspectives. Philosophical essays in honour of Prof. J.A.L. Taljaard. Potchefstroom. p. 359-379.)

1976a. Persvryheid in die Suid-Afrikaanse Reg. (In Coetzee, J.A., red Gedenkbundel: H.L. Swanepoel. Durban : Butterworths. p. 81-101.)

1976b. The overreach of the criminal law. (In Proceedings of the conference on "Crime, Law and the Community" held on 1-4 April 1975 at the University of Cape Town. Kaapstad/ Wynberg/Johannesburg : Juta. p. 53-58.)

1977. Censorship. (In Joubert W.A., ed. The law of South Africa vol 2. Durban : Butterworths. p. 93-186.)

1978a. Ridigity and flexibility in constitutions: The judiciary, the rule of law and constitutional amendment. (In Benyon, J., ed. Constitutional change in South Africa: Proceedings of the conference on "Constitutional Models and Constitutional Change in South Africa". Pietermaritzburg. p. 52-84.)

1978b. Prospects for the future political development of South Africa. (In De Crespigny, A. \& Schrire, R, eds. The government and politics of South Africa. Kaapstad/Wetton/ Johannesburg : Juta. p. 245-256.)

1978c. Euthanasia and the law. (In Oosthuizen G.C., Shapiro, H.A. \& Strauss, S.A., eds. Euthanasia. Kaapstad : Oxford University Press. p. 115-131.)

1979. The concept of human rights: Its history, contents and meaning. (In Forsyth, C.F. \& Schiller, J.E., eds. Human rights: The Cape Town conference. Proceedings of the first international conference on "Human Rights in South Africa", 22-26 January 1979. Kaapstad/Wetton/Johannesburg : Juta.p. 10-32 J

1980a. The legal status of the homo novis. (In Oosthuizen, G.C., Shapiro, H.A. \& Strauss, S.A., eds. Genetics and society. Kaapstad : Oxford University Press. p. 88-112.)

1980b Die kontrakteregtelike kompetensie van minderjariges. (In Joubert, D.J., red. Petere fontes: LC Steyn-gedenkbundel. Pretoria : Vereniging Hugo de Groot. p. 195-225.)

1982. Human rights aspects of the dual system applying to blacks in South Africa. (In Takirambudde, P.N., ed. The individual under African law. Swaziland : University of Swaziland. p. 130-42.)

1983a. General aspects of the South African censorship laws. (In Goggin, T., ed. Censorship Johannesburg : S.A. Institute of Race Relations. p. 9-36.)

1983b Law and morality. ( $n$ Kahn, Ellison, ed. Fiat iustitia: Essays in memory of Oliver Deneys Schreiner. Kaapstad/Wetton/Johannesburg : Juta. p. 305-369.)

1983c. State secrecy. (In Oosthuizen, G.C., Shapiro, H.A. \& Strauss, S.A., eds. Professional secrecy in South Africa Kaapstad : Oxford University Press. p. 48-57.)

1983d Regsgeneeskundige aspekte van die Perinatale Generica. (In Gericke, G.S. \& Op't Hof, J., reds. Aangebore en erflike afwykings: Basiese beginsels en praktyktoepassing Pretoria : HAUM. p. 27.1-27.16.)

1983e. The rights to life of the unborn in South African law. (In Kahn, Ellison, ed. The sanctity of life. University of the Witwatersrand : Senate Special Lectures. p. 6-12.)

1985. Legal dimensions of human experimentation. (In Oosthuizen, G.C., Shapiro, H.A. \& Strauss, S.A., eds Attitudes to clinical experimentation in South Africa. Johannesburg : Hodder \& Stoughton. p. 62-93.)

1986. Religion. (In Joubert, W.A. \& Scott, T.J., eds. The law of South Africa vol. 23. Durban : Butterworths. p. 175-202.) 
1988a. Reflections on individualism II. (In Marshall, Paul A. \& Vandervennen, Robert E. eds Social science in Christian perspective. Lanham: University Press of America p. 83-94.)

1988b. The doctrine of private-law rights. (In Strauss, S.A. ed. Huldigingsbundel vir W A. Joubert. Durban : Butterworths. p. 201-246.)

1989a. The étatisation of public property. (In Visser, D P. ed. Essays on the history of law $\mathrm{Kaapstad/Wetton/Johannesburg} \mathrm{:} \mathrm{Juta.} \mathrm{p.} \mathrm{261-299.)}$

1989b. The concept of political sovereignty. (In Visser, Coenraad ed Essays in honour of Ellison Kahn. Kaapstad/Wynberg/Johannesburg : Juta. p. 289-360.)

1996a. Introduction: Legal dimensions of religious human rights: Constitutional texts (In Van der Vyver, Johan D. \& Witte, John Jr eds Religious human rights in global perspective vol. 2: Legal perspectives Den Haag /Boston/Londen : Marinus Nijhoff p xj-xlvii.)

1996b Property in international human rights law. (In Van Maanen, G.E. \& Van der Walt, A.J eds. Property law on the threshold of the 21 st century. Antwerpen/Apeldoorn : MAKLU p. 451-486.)

1997. Constitutional protection of children and young persons. (In Robinson, J.A. ed. The law of children and young persons in South Africa. Durban : Butterworths. p. 265-320.)

\section{(iv) Vaktydskrifartikels ${ }^{4}$}

1962a. Die regsbegrip. Tydskrif vir Hedendaagse Romeinse-Hollandse Reg, 25(1): 1-15

1962b. Die regsleer van Aristoteles: 'n Probleemstelling Koers, 29(9 \& 10):224-260.

1964. Artikel 31 van die Wysigingswet op Bantoewetgewing, 1963. Tydskrif vir Hedendaagse Romeins-Hollandse Reg, 27(2):94-115.

1965a. Die gatsometer. Tydskrif vir Hedendaagse Romeinse-Hollandse Reg, 28(1):15-29

1965b. Die juridiese sin van die leerstuk van natuurlike menseregte Bulletin van die SuidAfrikaanse Vereniging vir die Bevordering van Christelike Wetenskap, 1(1):25-32

1966/67. Animus iniuriandi en die afwesigheid van wederregtelikheidsbewussyn. Tydskrif vir Hedendaagse Romeins-Hollandse Reg, 29(4):336-350 en 30(1): 15-39.

1967a Wederregtelikheidsbewussyn by strafregtelike aanspreeklikheid Tydskrif vir Hedendaagse Romeins-Hollandse Reg, 30(3):271-278.

1967b Privilegie, wederregtelikheid en skuld. Tydskrif vir Hedendaagse Romeins-Hollandse Reg, 30(4):370-374.

1968a. Maoki v. Reckett \& Colman (Africa) Ltd \& another, 1968 (1) S.A. 702 (W) Tydskrif vir Hedendaagse Romeins-Hollandse Reg, 31(3):289-290.

1968b Netherlands Insurance Co of South Africa Ltd. v. Van der Vyver, 1968 (1) SA 412 (A). Tydskrif vir Hedendaagse Romeins-Hollandse Reg, 31(3):295-297.

1968c. Neuhaus N O. v. Bastion Insurance Co. Ltd., 1968 (1) SA (A). Tydskrif vir Hedendaagse Romeins-Hollandse Reg, 31(4):393-394

1968d. Die sin-begrip in die Christelike wysbegeerte. Tydskrif vir Christelike Wetenskap, 4(1) $41-46$

1969. Reg en plig insake onregmatigheid. Koers, 37(2): 154-163.

4 Artikels word onder hierdie spesifieke hoof gelys hoofsaaklik na aanleiding van die wyse wat Van der Vyver self verkies om dit in sy lys van publikasies te vermeld. Sommige van die artikels is gepubliseer in tydskrifte wat normaalweg nie as "vaktydskrifte" deurgaan nie. Die artikels is egter bedoel om vakkundig te wees Van der Vyver het ook 'n vyf en vyftigtal populêre artikels geskryf (wat nie in die huidige lys opgeneem is nie) waarvan 'n hele aantal in erkende en geakkrediteerde vaktydskrifte gepubliscer is. Hiemaas is sy 17 artikels in die dagbladpers en sy 54 boekresensies ook nie by die huidige lys ingesluit nie 
Lourens du Plessis

1970 Die juridiese grondslag van besitsbeskerming. Tydskrif vir Hedendaagse RomeinsHollandse Reg, 33(3) 231-243

1971a. The relevancy of the irrelevancy of sex in the United States. The Comparative and International Law Journal of Southern Africa, 4(3):339-352.

1971b. The American concept of equality. Acta Juridica, :147-165

1972a. Godsdiensvryheid in die Verenigde State van Amerika. Bulletin van die SuidAfrikaanse Vereniging vir die Bevordering van Christelike Wetenskap, 32:40-54.

1972b. Kuyper en die Amerikaanse konsep van godsdiensvryheid. Bulletin van die SuidAfrikaanse Vereniging vir die Bevordering van Christelike Wetenskap, 32:13-24.

1973a. Bester v. Commercial Union Versekeringsmaatskappy van Suid-Afrika Bpk., 1973 (1) SA 769 (A). Tydskrif vir Hedendaagse Romeins-Hollandse Reg, 36(2):169-175

1973b. Regsubjektiwiteit. Tydskrif vir Hedendaagse Romeins-Hollandse Reg, 36(3):266-273.

1973c. (met Pretorius, H.N. as mede-outeur). Artikel 84 van die Insolvensiewet. Tydskrif vir Hedendaagse Romeins-Hollandse Reg, 36(4):396-411.

1974a. Reg en etiek. Perspektief, 13, Maart.

1974b. Brown v. Board of Education: A survey of the desegregation programme in the United States. The South African Law Journal, 91(4):491-514.

1974c. Die (r)evolusie in Suid-Afrika. Woord en Daad, 10-11, Des.

1974/75. Hedendaagse Calvinistiese en Roomskatolieke natuurregsteorieë. Tydskrif vir Hedendaagse Romeins-Hollandse Reg, 37(4):380-388, 38(1):66-75 en 38(2):119-139

1975a. Reg(ter) en geregtigheid. De Jure, 8(1):8-22.

1975b. The unruly horse: Reflections on the rule of law. Koers, 40(4, 5 \& 6):359-379

1976a. The function of legislation as an instrument for social reform. The South African Law Joumal, 93(1):56-67.

1976b. The principle of justice and equality. Revue des Droits de l'Homme/Human Rights Journal, $9(1): 21-38$

1976c. Die rol van die (regs-)wetenskap in die verandering van die menslike lewe. Bulletin ter Bevordering van Christelike Wetenskap, 48 en 49:5-17. (Ook gepubliseer in Verslag van een Samenspreking tussen Delegaties van de Vrije Universiteit en de Potchefstroomse Universiteit vir Christelike Hoër Onderwys. Amsterdam : Vrije Universiteit. 1976. p. 31-40 en in Perspektief, 15:18-33.)

1977a. Artikel 6 van die Wet op Terrorisme. Suid-Afrikaanse Tydskrif vir Strafreg en Kriminologie, 1(2):171-177

1977b. Die swygreg van kerkleraars. Tydskrif vir Hedendaagse Romeins-Hollandse Reg, 40(3):217-232

1977c. The state, the individual and society. The South African Law Journal, 94(2): 291-305.

1977d. The state and society. Perspektief, 16 en 17:59-88.

1977e. Pornografie, sensuur en reg: Nie vir regsgeleerdes nie. Tydskrif vir Regswetenskap, 2(2):117-126.

1977f. The future prospects for the protection of human rights in South Africa. Koers, 42(6) 473-496.

1978a. Staatsabsolutisme in Suid-Afrika. Perspektief, 17:63-81

1978b. Actiones populares and the problem of standing in Roman, Roman-Dutch, South African and American law Acta Juridica : 191-205

1979a. Verskyningsbevoegdheid van minderjariges. Tydskrif vir Hedendaagse RomeinsHollandse Reg, 42(2): 129-141

1979b. Conscientious objections against warfare: A juridical perspective from the Calvinistic point of view Philosophical Papers, 8:56-63

1979c. Beperkte en volledige emansipasie. Tydskrif vir Hedendaagse Romeins-Hollandse Reg, 42(3):309-315. 
1979d. Die relevansie van minderjarigheid op die gebied van die strafregspleging De Rebus, 465-468.

1979e. The case of a sterile father. The South African Law Journal, 96(3):435-439.

1979f. Veiligheidswetgewing in Suid-Afrika Woord en Daad, 14-15, Des

1980a. V v. R 1979 (3) SA 1006 (T). Tydskrif vir Hedendaagse Romeins-Hollandse Reg, 43(1):89-96.

1980b. Inperkingsbevele. Tydskrif vir Hedendaagse Romeins-Hollandse Reg, 43(2) 178-187

1980c. Law, order and society. Tydskrif vir Hedendaagse Romeins-Hollandse Reg, 43(3):278292.

1980d. The section 114 controversy - and governmental anarchy. The South African Law Journal, 97(3):363-374.

1980e Politieke selfbeskikking, die regsidee en menseregte. Codicillus, 21:4-9, Okt

1981a. Die verskyningsbevoegdheid van vakverenigings. Industrial Law Journal, 2(1):1-15.

1981b. Qu'ils mangent de la brioche. The South African Law Journal, 98(2):135-148.

1981c. Regsekerheid. Tydskrif vir Hedendaagse Romeins-Hollandse Reg, 44(3) 269-280

1981d. Christian League of Southern Africa v. Rall, 1981 (2) SA 821 (O). Tydskrif vir Hedendaagse Romeins-Hollandse Reg, 44(3):305-314

1981e Die Nywerheidshof. Industrial Law Journal, 2(3):159-165

1981f. State Security, Human Rights and the Rule of Law. Politikon, $9(1): 52-58$

1982a Kantaantekeninge by die Wet op Binnelandse Veiligheid. Tydskrif vir Hedendaagse Romeins-Hollandse Reg, 45(3):294-309.

1982b. Parliamentary sovereignty, fundamental freedoms and a Bill of Rights. The South African Law Journal, 99(4):557-588.

1982c. Human rights aspects of the dual system applying to blacks in South Africa. The Comparative and International Law Journal of South Africa, 15(3):306-318

1983a. Die regsfilosofie van Hugo de Groot. Tydskrif vir Hedendaagse Romeins-Hollandse Reg, 46(2):151-171.

1983b. Legal aspects of drug control in South Africa. De Jure, 16(1):154-173.

1983c. Subjectivity and objectivity of fault: The problem of accountability and negligence in delictual liability. The South African Law Journal, 100(4):575-593

1984a. Menseregte in perspektief. Woord en Daad, 13-14, Maart.

1984b Ras as nywerheidsbelang. Industrial Law Journal, 5(4):302-306.

1985a. The Bill-of-Rights issue. Tydskrif vir Regswetenskap, 10(1): 1-20

1985b. Depriving Westminster of its moral constraints: A survey of constitutional development in South Africa. Harvard Civil Rights/Civil Liberties Law Review, 20:291-337.

$1985 \mathrm{c}$. Women in politics and public administration. South African Journal on Human Rights, 1(1): $63-69$

1985d. The laughing policeman. South African Journal on Human Rights, 1(2):165-169.

1985/86. The Coventry Four: Another perspective. South African Yearbook of International Law, 157-166.

1986a. Rassendiskriminierung, Verfassungsreform und Unruhe in Sudafrika. Liberal, 28:3951

1986b. Judicial Review under the new Constitution. The South African Law Journal, 103(2):236-258

1986c. Passports, privilege and precedent. The South African Law Journal, 103(3):356-367

1986d. The 1983 Constitution: An exercise in consociationalism? South African Journal on Human Rights, 3(3):341-349

1987a. Political power constraints and the American constitution. The South African Law Journal, 104(3) 416-438 
Lourens du Pless/s

1987b. Judicial self-sufficiency in Omar. South African Joumal on Human Rights, 3(3):335337.

1988a. Expropriation, rights, entitlements and surface support of land. The South African Law Journal, 105(1):1-16

1988b. State sponsored terror violence South African Journal on Human Rights, 4(1):55-75.

1988c. The state president and indemnity under the Defence Act. South African Journal on Human Rights, 4(2):153-166.

1989a. The jural credo: Justice as the essence of legal ethics and a component of positive law. Tydskrif vir Hedendaagse Romeinse-Hollondse Reg, 52(2):157-183

1989b. Comments on the Constitutional Guidelines of the African National Congress. South African Journal on Human Rights, 5(2): 133-153

1989c. The South African Law Commission's Provisional Report on Group and Human Rights. The South African Law Journal, 106(3):536-546

1989d. The rights to medical care. Medicine and Law, 7:579-583

1990. Legal perspective of the concept of life. Medicine and Low, 9:675-683

1991a. Statehood in international law. Emory International Law Revew, 5:9-102

1991b. Constitutional options for post-apartheid South Africa. Emory Law Journal, 40:745835

1991c. Sovereignity and human rights in constitutional and international law. Emory International Law Review, 5:321-443

1992. State sovereignity and the environment in international law. The South African Law Journal, 109 (3) 472-495

1993. The separation of powers. SA Publiekreg/Public Low, 8(2):177-191

1994a. Comparative Law in constitutional litigation. The South African Law Journal, 111 (1) 19-31

1994b. Limitation provisions of the Bophuthatswana Bill of Rights. Tydskrif vir Hedendaagse Romeins-Hollandse Reg, 57(1):47-74

1994c. Suspension, derogation and de facto deprivation of fundamental rights in Bophuthatswana. Tydskrif vir Hedendaagse Romeins-Hollandse Reg, 57(2):257-278

1994d. The private sphere in constitutional litigation. Tydskrif vir Hedendaagse RomeinsHollandse Reg, 57(3) 378-395

1994e. The meaning of "law" in the Constitution of the Republic of South Africa. The South African Law Journal, 11 l(3):569-576

1994f. Stoker se denke aangaande die reg en geregtigheid. Koers, 59(3 \& 4):403-434

1995. Constitutional free speech and the law of defamation. The South African Law Journal, $112(4): 572-602$

1996. Religious fundamentalism and human rights. Journal of Intemational Affairs, 50.1:21. 40

1997. Constitutionality of the Age of Majority Act. The South African Law Journal, 114 (4) $750-760$

1998a. Introduction to the public conference addressing "Religious Liberty in the United States" Emory International Law Review, 12:935-944

1998b. Universality and relativity of human rights: American relativism. Buffalo Human Rights Law Review, 4:43-78

1998c. Gelykberegtiging. Tydskrif vir Hedendaagse Romeins-Hollandse Reg, 61(3):367-399

1998d. Religious freedom and proselytism: Ethical, political and legal aspects. The Ecumenical Review, 50.4:419-429. 


\section{(v) Gepubliseerde lesings 5}

1975. Legislation as an instrument for social reform. (In Proceedings of the National Conference on "Social Betterment and Reform", sponsored by the Churches of Scientology, October 1975. p. 7-13.)

1976a. Die beskerming van menseregte en van minderhede in onafhanklike Suidwes (In Die toekoms van Suidwes Afrika: 'n Oop gesprek/The future of South West Africa: An open discussion, Windhoek, Februarie 1976. p. 21-24.)

1976b. The Dakar conference on Namibia and human rights. (In South West Africa/Namibia A symposium, South African Institute for International Affairs, Braamfontein, May 1976, p $1-6$ )

1976c General theories of human rights (summary of lectures)/Theorie generale des droits de l'homme (résumé des cours). (In Summary of lectures, seventh study session of the International Institute of Human Rights/Résumé des cours, septième session d'enseignement du Institut Inter-National des Droits des l'Hommes, Strasbourg, July 1976. p. AJV 1-24 en p. F/JVV 1-20.)

1977. Die juridiese faset van geregtigheid in die Suid-Afrikaanse samelewing. (In Geregtigheid in die Suid-Afrikaanse samelewing. Potchefstroom : Instituut vir die Bevordering van Calvinisme. p. 58-82.)

1978. On human rights. (In Mutatis mutandis: A collection of papers presented at the National Conference of South African Law Students, Law Students Council, University of the Witwatersrand 1978. p. 63-67.)

1979. The function of the press in the face of excessive governmental powers. (In South African Conference on the Survival of the Press and Education for Joumalism, 4-6 October 1979, Grahamstown.)

1980. Norms for the international economic order. (In Justice in the international economic order: Proceedings of the Second International Conference of Reformed Institutions for Christian Higher Education, Calvin College, Grand Rapids, Michigan, 13-19 August 1978. Grand Rapids p. 254-267.)

1981 Graduation address (In Gazette of the University of the Witwatersrand, 59, July $1981 \mathrm{p}$ 5-10.)

1989. Legal and constitutional prospects of post-apartheid South Africa (In Breytenbach, Rosalie ed. 1989 Standard Bank National Arts Festival Winter School. Grahamstown : 1820 Foundation. p. 49-53.)

1991. Human rights in sport. (In First Congress of the Olympic Academy of South Africa, University of Port Elizabeth, Port Elizabeth, OASA OLYMPISM, 26-28 June 1990. p. 29-40.)

1993. Perceptions of democracy. (In Institute for Reformational Studies: Democracy in Africa. Potchefstroom. p. 1-38.)

1994 Discrimination and the law: Philosophical and constitutional perspectives (In Heyns, Christof, Van der Westhuizen, Johann \& Mayimele-Hashatse, Tshidi, eds. Discrimination and the law, vol. 1. A multi-disciplinary inquiry into de facto racial discrimination. Pretoria : Centre for Human Rights Study p. 31-33.)

5 Baie van Van der Vyver se lesings is in ander vorme (bv. as artikels in vaktydskrifte of hoofstukke in boeke) gepubliseer. Onder die huidige hoof word spesifiek verwys na gepubliseerde konferensieverrigtinge wat nie elders vermeld word nie 
1995. The doctrine of human rights: Its historical and philosophical foundations. (In Brand, Danie, Heyns, Christof, De Meyer, Isabeau \& Maitland, Graham, eds. From human wrongs to human rights. Part IV. Pretoria : Centre for Human Rights Studies. p 48-56.)

1996. The self-determination of minorities and sphere sovereignty. (In Are international institutions doing their job? Washington D C. The American Association of International Law: Proceedings of the 90th Annual Meeting. March 27-30 1996. p. 211-214.)

\section{Bibliografie 6}

\section{Werke van ander outeurs waarna in hierdie artikel verwys word}

CORDER, H. \& DAVIS, Dennis 1988 Law and social practice: An introduction. (In Corder, Hugh, ed. Essays on law and social practice in South Africa. Kaapstad/Wetton/ Johannesburg : Juta. p. 1-30.)

DUGARD, John. 1971. The judicial process, positivism and civil liberty. The South African Law Joumal, 88(2): 181-200.

DUGARD, John 1978. Human rights and the South African legal order. Princeton, New Jersey : Princeton University Press.

DU PLESSIS, L.M. 1978. Die juridiese relevansie van Christelike geregtigheid. Potchefstroom PU vir CHO

DU PLESSIS, Lourens M. 1981. L.J. du Plessis as regsdenker. Koers, 46(1):31-69.

DU PLESSIS, Lourens M. 1990. Enkele opmerkings oor die Christelike fundering (en verwerping) van menseregte. Tydskrif vir Hedendaagse Romeins-Hollandse Reg, 53(3):403-412.

DU PLESSIS, Lourens M. 1996 Legal academics and the open community of constitutional interpreters. South African Journal on Human Rights, 12(2):214-229

DU PLESSIS, Lourens. 1999. Inleiding tot die reg. 3de uitg. Kenwyn : Juta.

DYZENHAUS, David. 1982. L.C. Steyn in perspective. The South African Law Journal, 99(3):380-393

DYZENHAUS, David. 1983. Positivism and validity. The South African Law Journal, 100(3):454-467

FORSYTH, C.F. \& SCHILLER, J.E., eds. 1979 Human rights: The Cape Town conference Proceedings of the First International Conference on "Human Rights in South Africa", 2226 January 1979. Kaapstad/Wetton/Johannesburg : Juta

HUND, John \& VAN DER MERWE, H.W. 1986. Legal ideology and politics in South Africa: A social science approach. Kaapstad : Centre for Intergroup Studies/University Press of America

JOUBERT, W A. 1958 Die realiteit van die subjektiewe reg en die betekenis van 'n realistiese begrip daarvan vir die privaatreg Tydskrif vir Hedendaagse Romeins-Hollandse Reg, 21(1):12-15 en (2):98-115

KLUG, Heinz. 1997. Introducing the Devil: An institutional analysis of the power of constitutional review. South African Joumal on Human Rights, 13(2): 185-207

MATHEWS, A S. 1971 Law order and liberty in South Africa. Kaapstad/Wetton/ Johannesburg : Juta

MATHEWS, A S. 1986. Freedom, state security and the rule of law. Kaapstad/Wetton/ Johannesburg : Juta

6 Die bibliografiese gegewens van die tersaaklike publikasies van Van der Vyver waarna in hierdie artikel verwys word, kan gevind word in afdeling 9 van die artikel. 
POTGIETER, J.M. 1989. Gedagtes oor die nie-Christelike aard van menseregte. Tydskrif vir Hedendaagse Romeins-Hollandse Reg. 52(3):386-408.

STOKER, H.G. 1967. Oorsprong en rigting I. Kaapstad : Tafelberg.

STOKER, H.G. 1970. Die aard en rol van die reg - 'n wysgerige besinning. Johannesburg Publikasiereeks van die RAU, A. 36.

VAN BLERK, A. 1984. The genesis of the "modernist-purist" debate: A historical bird's-eye view. Tydskrif vir die Hedendaagse Romeins-Hollandse Reg, 47(3):255-279

VAN DER WALT, A.J. 1986. Relatiewe saaklike regte? Tydskrif vir die Suid-Afrikaanse Reg, 1986(2): 173-179.

VAN DER WALT, A.J. 1990. The doctrine of subjective rights: A critical reappraisal from the fringes of property law. Tydskrif vir Hedendaagse Romeins-Hollandse Reg, 53(3):316329.

VAN DER WALT, A.J. 1995. Kritiese vrae oor die leerstuk van subjektiewe regte in die SuidAfrikaanse regsleer. De Jure, 28(1):43-60.

VENTER, F. 1985. Die publiekregtelike verhouding. Durban : Butterworths

VENTER F. 1991. Die publieke subjektiewe reg - 'n voorraadopname Tydskrif vir Hedendaagse Romeins-Hollandse Reg, 54(3):349-366.

VENTER, F., VAN DER WALT, C.F.C., VAN DER WALT A.J., PIENAAR, G.J., OLIVIER, N.J.J \& DU PLESSIS, L.M. 1990. Regsnavorsing: Metode en publikasie. Kaapstad/Wetton/Johannesburg : Juta.

WIECHERS, M. 1988. Die publieke subjektiewe reg. (In Strauss, S.A. red. Huldigingsbundel vir W.A. Joubert. Durban : Butterworths. p. 270-291.) 